\title{
EMPIRICAL ANALYSIS AND INTERVENTION RESEARCH ON THE INFLUENCING FACTORS OF COLLEGE STUDENTS' PHYSICAL HEALTH
}

\author{
ANÁLISE EMPÍRICA E INVESTIGAÇÃO DA INTERVENÇÃO SOBRE OS FATORES QUE INFLUENCIAM A SAÚDE \\ FÍSICA DOS ESTUDANTES UNIVERSITÁRIOS
}

ARTIGO ORIGINAL

Artículo Original

\section{ANÁLISIS EMPÍRICO E INVESTIGACIÓN DE INTERVENCIONES SOBRE LOS FACTORES QUE INFLUYEN EN LA SALUD FÍSICA DELOS ESTUDIANTES UNIVERSITARIOS}

\section{Bo Xul (D) \\ Sports Sociology}

1. Xi'an Siyuan University, Xi'an, Shanxi, 710038, China.

Correspondence: Shanxi, 710038, China. gen68434@yeah.net

\begin{abstract}
Since the reform and opening up, China's national living standards have gradually improved, but the current physical health level of college students has not increased with the improvement of living standards. The physical health of college students - as high-quality talents of the country - is related to the future of the country and the nation,. In order to explore the influencing factors of college students' physical health, the analytic hierarchy process (AHP) was used to evaluate the factors affecting students' physical health. This study analyzes the index of students' physical health through the method of literature, then revises the evaluation index through expert analysis and analytic hierarchy process, and verifies it through examples. The results show that the final score of the school students' physical health is 81.55 , of which the school factor has the greatest impact on the students' physical health, and the school factor score is far from the expected score. We can promote the development of students' physical exercise and improve the level of students' physical health through the improvement of school sports management. This study provides reference for the healthy development of public sports students in China.
\end{abstract}

Keywords: Physical health; analytic hierarchy process; evaluation index; sports.

\section{RESUMO}

Desde a reforma e a abertura, o padrões de vida nacional da China melhorou gradualmente, mas o atual nível de saúde física dos estudantes universitários não aumentou com a melhoria do padrões de vida. A saúde física dos estudantes universitários - como talentos de alta qualidade do país - SU está relacionada com o futuro do país e da nação. A fim de explorar os fatores que influenciam a saúde física dos estudantes universitários, utilizou-se o processo hierárquico analítico (AHP) para avaliar os fatores que afetam a saúde física dos estudantes. Este estudo an alisa o índice de saúdefíisica dos estudantes a través do método da literatura, e analisa o índice de avaliação sob a ótica de especialistas e pelo processo hierárquico analítico, everifica o índice por meio de exemplos. Os resultados mostram que a pontuação final da saúde física dos alunos é 81.55, do qual o fator escolar tem o maior impacto sobre a saúde física dos alunos, e a pontuação do fator escolar está longe da contagem esperada. Podemos promover o desenvolvimento do exercício físico dos alunos e melhorar o nivel de sua saúde física através da melhoria da gestão do desporto escolar. Este estudo fornece referências para o desenvolvimento saudável de estudantes de esportes públicos na China.

Descritores: Salud física; análisis jerárquico; indicadores de evaluación; deporte.

\section{RESUMEN}

Desde la reforma y la apertura, los niveles de vida nacionales de China han mejorado gradualmente, pero el nivel actual de salud física de los estudiantes universitarios no ha aumentado con la mejora de los niveles de vida. La salud física de los estudiantes universitarios, como talentos de alta calidad del país, está relacionada con el futuro del país y de la nación. Con el fin de explorar los factores que influyen en la salud física de los estudiantes universitarios, se utilizó el proceso de jerarquía analítica (PJA) para evaluar los factores que afectan la salud física de los estudiantes. Este estudio analiza el índice de salud física de los estudiantes a través del método de la literatura, luego revisa el índice de evaluación a través del análisis de expertos y el proceso de jerarquía analítica, y lo verifica mediante ejemplos. Los resultados muestran que el puntaje final de la salud física de los estudiantes de la escuela es 81.55, de los cuales el factor escuela tiene el mayor impacto en la salud física de los estudiantes, y el puntaje del factor escuela está lejos del puntaje esperado. Podemos promover el desarrollo del ejercicio físico de los estudiantes y mejorar el nivel de salud física de los estudiantes mediante la mejora de la gestión deportiva escolar. Este estudio proporciona una referencia para el desarrollo saludable de los estudiantes de deportes públicos en China.

Descriptores: Saúde física; processo hierárquico analítico; índice de avaliação; desporto. 


\section{INTRODUCTION}

Today, with the rapid development of national economy, culture and science and technology, the physical health of college students, who are the future successors of the country, is worrying. According to the data of the Ministry of education of the people's Republic of China, the physical health level of college students in China is gradually declining, and will continue to decline in the next few years. ${ }^{1}$ A strong youth makes a strong country, and progress means progress. The physical health of college students is related to the future of the country and the nation. Therefore, it is urgent to find out the influencing factors of College Students' physical health and improve their physical fitness level. As an effective method to improve students' physical health, physical exercise should be paid attention to. However, the current situation of College Students' physical exercise is not ideal, and college students'sports activities are restricted in many aspects. ${ }^{2}$ To make clear the influencing factors of students' physical health is a prerequisite to improve the level of College Students' physical health. Therefore, this study has carried out a study on the factors affecting students' physical health, hoping to lay a solid foundation for the further development of College Students' physical health.

In order to improve the physical and mental health of sports personnel, Bezyak et al. Proposed to evaluate the physical and mental health of college students. Through the research on the sports activities and mental health of 24 students, the results showed that the current physical and mental health of college students was generally sub-health. ${ }^{3}$ Wang $m$ et al. proposed to study the physical and mental health of college students by means of literature survey, questionnaire survey and sorting statistics, and analyzed the physical and mental health status of 70 college students. The results show that muscle gain can have a positive impact on physical and mental health. ${ }^{4}$ In this study, the volunteers were divided into intervention group and non intervention group. The intervention group was given certain physical exercise every day. The results showed that the body weight of the intervention group showed a downward trend, and the cardiopulmonary systolic pressure also decreased with the weight loss. ${ }^{5}$ Eisenstadt et al. studied the physical exercise ability and aerobic fitness level of adolescents and adults in CF center of hadassad medical center in Jerusalem, Israel. The research used the method of comparing physical activity questionnaire and exercise test evaluation to evaluate the exercise ability and aerobic ability level of CF patients. Studies have shown that male patients have higher aerobic fitness and exercise ability than female patients with CF. ${ }^{6}$ Through the methods of literature, questionnaire, mathematical statistics, logical analysis and other research methods, Liao Xiaoging made a survey on the current situation of the physical exercise habits of the ordinary students in Jimei University. The results showed that the proportion of the ordinary students in Jimei University was low, their demand for exercise was weak, and their interest in exercise was unstable; Less time and energy are invested in physical exercise.? According to the type, intensity and duration of intervention, Melissa et al. systematically analyzed the effect of physical exercise on male cardiopulmonary function by using the method of randomized clinical trial. The results show that both aerobic exercise and resistance exercise have positive effects on VO2 of men of different age groups, indicating that exercise has a positive effect on cardiopulmonary function.

Through the research and analysis of scholars at home and abroad, we can see that AHP can be used in various fields. This study not only uses the analytic hierarchy process, but also validates the research index by expert analysis method. It is hoped that this study can provide some reference for the further development of College Students' physical health in China.

\section{Experimental design and Analysis}

This study selected a university in a city as the research object. In order to ensure the preciseness of the experiment, a total of 10 experts in related fields were consulted through telephone interview, email consultation and door-to-door visit. The rationality of the evaluation indicators used in this study was verified. The Table 1 shows the comparison matrix, weight vector and one of the first-class indicators in the study.

It can be seen from the above table that the consistency ratio index $C R$ of the first level index in this study is less than 0.1 , so it can be considered that the first level index and its judgment matrix selected in the study meet the consistency requirements. And through the table, we can see the weight of the first level indicators in this study. The weight of personal factor $\mathrm{A}$ is 0.15 , that of family factor $B$ is 0.18 , that of school factor $C$ is 0.451 , and that of social factor $D$ is 0.219 . After the weight of the first level index is obtained and its consistency meets the requirements, the same method is used to calculate the secondary index. The Table 2 shows the comparison matrix, weight vector and consistency test results of the secondary index in this study.

It can be seen from the above table that the consistency ratio index CR of the four secondary indicators in personal factor $A$ is 0.063 , and its value is less than 0.1 . Therefore, the secondary indicators and their judgment matrix belonging to a meet the consistency requirements, and the weight of the secondary indicators is $0.150,0.180,0.451,0.219$, respectively. The consistency ratio index $C R$ of secondary indicators in family factor B is 0.046 , which is far less than 0.1. Therefore, the secondary indicators and their judgment matrix belonging to $B$ meet the requirements of consistency, and the weights of secondary indicators

Table 1. The weight of the first-level evaluation index is the consistency test.

\begin{tabular}{|c|c|c|c|c|c|c|c|c|}
\hline $\begin{array}{l}\text { First-level } \\
\text { indicators }\end{array}$ & A & B & C & D & $\lambda_{\max }$ & $\mathrm{Cl}$ & RI & CR \\
\hline$A$ & 1 & $1 / 2$ & $1 / 3$ & 1 & \multirow{4}{*}{4.17} & \multirow{4}{*}{$\left(\lambda_{\max }-4\right) / 3=0.0057$} & \multirow{4}{*}{0.90} & \multirow{4}{*}{0.063} \\
\hline B & 2 & 1 & $1 / 3$ & 2 & & & & \\
\hline C & 3 & 3 & 1 & 2 & & & & \\
\hline $\mathrm{D}$ & 1 & $1 / 2$ & $1 / 2$ & 1 & & & & \\
\hline$W_{1}$ & \multicolumn{8}{|c|}{$W_{1}=(0.150,0.180,0.451,0.219)$} \\
\hline
\end{tabular}

Table 2. The weight of the secondary evaluation index is the consistency test.

\begin{tabular}{|c|c|c|c|c|c|c|c|c|}
\hline $\begin{array}{l}\text { Secondary } \\
\text { indicators }\end{array}$ & A1 & A2 & A3 & A4 & $\lambda_{\max }$ & $\mathrm{Cl}$ & RI & $\mathrm{CR}$ \\
\hline A1 & 1 & $1 / 2$ & $1 / 3$ & 1 & \multirow{4}{*}{4.17} & \multirow{4}{*}{$\left(\lambda_{\max }-4\right) / 3=0.0057$} & \multirow{4}{*}{0.90} & \multirow{4}{*}{0.063} \\
\hline $\mathrm{A} 2$ & 2 & 1 & $1 / 3$ & 2 & & & & \\
\hline A3 & 3 & 3 & 1 & 2 & & & & \\
\hline A4 & 1 & $1 / 2$ & $1 / 2$ & 1 & & & & \\
\hline$W_{1}$ & \multicolumn{8}{|c|}{$W_{1}=(0.150,0.180,0.451,0.219)$} \\
\hline $\begin{array}{l}\text { Secondary } \\
\text { indicators }\end{array}$ & B1 & B2 & B3 & & $\max$ & $\mathrm{Cl}$ & RI & CR \\
\hline B1 & 1 & $1 / 2$ & 2 & \multirow{3}{*}{\multicolumn{2}{|c|}{3.05}} & \multirow{3}{*}{$\left(\lambda_{\max }-3\right) / 2=0.0027$} & \multirow{3}{*}{0.58} & \multirow{3}{*}{0.046} \\
\hline B2 & 2 & 1 & 2 & & & & & \\
\hline B3 & $1 / 2$ & $1 / 2$ & 1 & & & & & \\
\hline$W_{2}$ & \multicolumn{8}{|c|}{$W_{2}=(0.31,0.49,0.20)$} \\
\hline $\begin{array}{l}\text { Secondary } \\
\text { indicators }\end{array}$ & C1 & C2 & C3 & $\mathrm{C4}$ & $\lambda_{\max }$ & $\mathrm{Cl}$ & RI & CR \\
\hline $\mathrm{C} 1$ & 1 & 2 & 2 & 3 & \multirow{4}{*}{4.01} & \multirow{4}{*}{$\left(\lambda_{\max }-4\right) / 3=0.0035$} & \multirow{4}{*}{0.9} & \multirow{4}{*}{0.004} \\
\hline $\mathrm{C} 2$ & $1 / 2$ & 1 & 1 & 2 & & & & \\
\hline C3 & $1 / 2$ & 1 & 1 & 2 & & & & \\
\hline C4 & $1 / 3$ & $1 / 2$ & $1 / 2$ & 1 & & & & \\
\hline$W_{3}$ & \multicolumn{8}{|c|}{$W_{3}=(0.424,0.227,0.227,0.122)$} \\
\hline $\begin{array}{l}\text { Secondary } \\
\text { indicators }\end{array}$ & D1 & D2 & D3 & D4 & $\lambda_{\max }$ & $\mathrm{Cl}$ & RI & CR \\
\hline D1 & 1 & 1 & 3 & 2 & \multirow{4}{*}{4.01} & \multirow{4}{*}{$\left(\lambda_{\max }-4\right) / 3=0.002$} & \multirow{4}{*}{0.9} & \multirow{4}{*}{0.002} \\
\hline D2 & 1 & 1 & 3 & 2 & & & & \\
\hline D3 & $1 / 3$ & $1 / 3$ & 1 & $1 / 2$ & & & & \\
\hline D4 & $1 / 2$ & $1 / 2$ & 2 & 1 & & & & \\
\hline$W_{4}$ & \multicolumn{8}{|c|}{$W_{4}=(0.350,0.350,0.110,0.190)$} \\
\hline
\end{tabular}


are 0.31, 0.49 and 0.20, respectively. The consistency ratio index CR of secondary indicators under school factor $C$ is 0.004 , less than 0.1 , so the secondary indicators and their judgment matrix belonging to $\mathrm{C}$ meet the consistency requirements, and the weight of secondary indicators is $0.424,0.227,0.227,0.122$, respectively. Similarly, the consistency ratio index CR of the secondary indicators in social factor D is 0.002 , and its value is less than 0.1. Therefore, the secondary indicators and their judgment matrix belonging to $d$ meet the consistency requirements, and the weight of secondary indicators is $0.350,0.350,0.110,0.190$ respectively.

After verifying the consistency of the evaluation indicators selected in this study, the research conducted a survey and evaluation on the students of the school by means of questionnaires. The full score of each evaluation index is 100 points. A total of 500 questionnaires were distributed and 358 questionnaires were collected. The questionnaires with incomplete data, damaged questionnaires and dirty data were removed. After simple pretreatment, a total of 303 complete questionnaires were sorted out. The average score in the questionnaire was taken as the final score of each index. The following Table 3 shows the survey situation of this study.

The scores of each evaluation index in this study are shown in Table 3 above. After calculation, the score of level I index a is 11.4384 points, that of level I index B is 13.2372 points, that of level I Index C is 38.282233 points, and that of level I index D is 18.58872 points, with a total score of 81.55 points. The overall situation is correct. According to the weight of indicators at all levels, the full score is calculated as 100 points. The expected score and actual score of the index are shown in Figure 1 below.

As can be seen from the above figure, the difference between the actual score of school factor $C$ and the expected score is the largest in the first level index, which indicates that there are still some problems to be solved in promoting the physical health of college students in public sports. Reasonable adjustment of class hours can be used to avoid the occupation of physical education class; physical education hardware facilities are added to meet the needs of each student's sports activities and invite professional sports talents to conduct sports guidance and other methods to promote the healthy development of students' physique. In the secondary indicators, physical exercise habits and family physical exercise atmosphere have the most difference with the expected score. These two factors are actually related to each other. To improve these two aspects, the whole family can participate in sports activities together to cultivate the atmosphere of family physical exercise and make the whole family develop the habit of physical exercise used to it.

Table 3. Survey results.

\begin{tabular}{|c|c|c|c|c|}
\hline \multicolumn{2}{|c|}{ First-level indicators } & \multicolumn{2}{|l|}{ Secondary indicators } & \multirow{2}{*}{$\begin{array}{c}\text { Score } \\
\text { Actual score }\end{array}$} \\
\hline Index content & Weights & Index content & Weights & \\
\hline \multirow{4}{*}{ personal reason $\mathrm{A}$} & \multirow{4}{*}{0.150} & Is there time for physical exercise $\mathrm{A} 1$ & 0.150 & 82 \\
\hline & & Interest in sports A2 & 0.180 & 73 \\
\hline & & Physical exercise habits A3 & 0.451 & 68 \\
\hline & & Are there any sports partners A4 & 0.219 & 92 \\
\hline \multirow{3}{*}{ Family Factors B } & \multirow{3}{*}{0.180} & Parents believe that only study is important B1 & 0.310 & 68 \\
\hline & & Family physical exercise atmosphere B2 & 0.490 & 74 \\
\hline & & Parents' awareness of physical exercise B3 & 0.200 & 81 \\
\hline \multirow{4}{*}{ School factor $C$} & \multirow{4}{*}{0.451} & Physical education class occupied C1 & 0.424 & 82 \\
\hline & & Reasonable level of physical education curriculum C2 & 0.227 & 85 \\
\hline & & School hardware meets student sports C3 & 0.227 & 96 \\
\hline & & Professional guidance C4 & 0.122 & 74 \\
\hline \multirow{4}{*}{ Social factors D } & \multirow{4}{*}{0.219} & The importance of society to sports D1 & 0.350 & 87 \\
\hline & & Society's publicity work on physical exercise D2 & 0.350 & 79 \\
\hline & & Use physical examination as an official subject D3 & 0.110 & 88 \\
\hline & & Proportion of physical examination in talent selection D4 & 0.190 & 90 \\
\hline
\end{tabular}

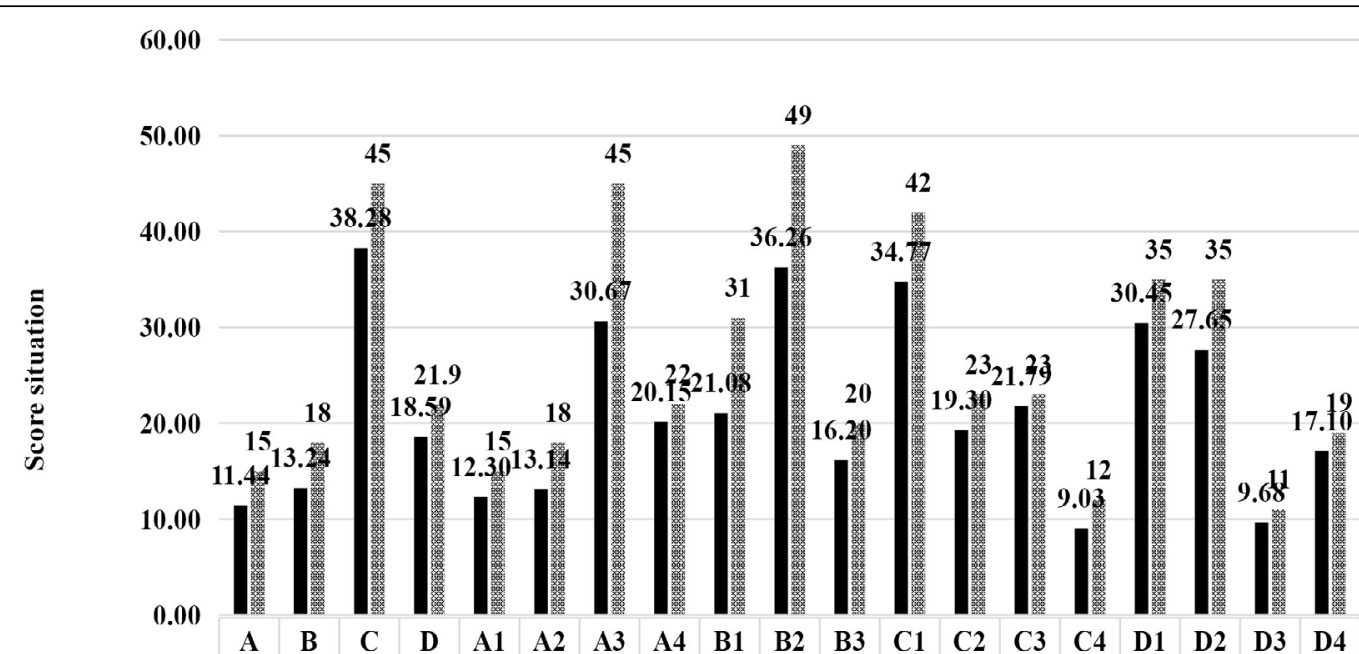

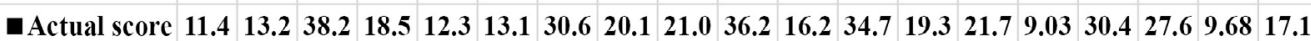

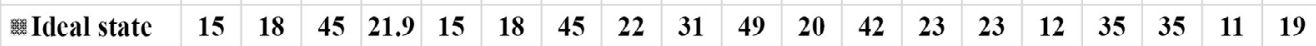

Evaluation index

Actual score 䉯 Ideal state

Figure 1. The ideal score and actual score of each indicator. 


\section{CONCLUSIONS}

College Students' myopia rate and obesity rate are increasing year by year, which reflects that there are many problems in college students' physical health. In order to explore the factors affecting the physical health of college students in China, this study uses the methods of literature, expert consultation and analytic hierarchy process to study the physical health of college students, and verifies the method through examples. In this study, a number of evaluation indicators are selected in a scientific and reasonable way, and the evaluation system affecting college students' physical health is established by using analytic hierarchy process. The results show that the school factor is the biggest factor affecting the physical health of college students in public physical education, and in the study found that there are many problems in the training of students physical exercise in Colleges and universities. We hope that through this study, we can improve the physical health of college students in public sports, and provide follow-up power for the development of our country.

The author declare no potential conflict of interest related to this article

AUTHORS' CONTRIBUTIONS: The author has completed the writing of the article or critical comments on its knowledge content. This paper can be used as the final manuscript. Every author has made an important contribution to this manuscript. Bo Xu: written and executed.

\section{REFERENCES}

1. Takabayashi K, Takahashi T, Oki S, Nagasawa T, Hinohara S. The healthy literacy support system for mind and body in clinical survey-Explanation and meaning of the system. Health Evaluation \& Promotion. 2015; 42(6):637-649.

2. van Waart $H$, Stuiver MM, van Harten WH, Geleijn E, Kieffer JM, Buffart LM, et al. Effect of Low-Intensity Physical Activity and Moderate- to High-Intensity Physical Exercise During Adjuvant Chemotherapy on Physical Fitness, Fatigue, and Chemotherapy Completion Rates: Results of the PACES Randomized Clinical Trial. Journal of Clinical Oncology. 2015; 33(17):1918-1927.

3. Bezyak J, Clark A. Promoting Physical and Mental Health Among College Students: A Needs Assessment. Rehabilitation Research Policy \& Education. 2016; 30(2):188-192

4. Wang $M$, Song $Y$, Qin $H$. Experimental study on the influence of exercise intervention on the physical and mental health of contemporary college students. Boletin Tecnico/Technical Bulletin. 2017; 55(15):456-461

5. Floody PD, Navarrete FC, Elgueta HO , Díaz MC, Mayorga DJ, Poblete AO. Effects of a structured physical exercise program on levels of physical fitness and nutritional status of the morbidly obese and obese with comorbidities. Nutricion hospitalaria: organo oficial de la Sociedad Espanola de Nutricion Parenteral y Enteral. 2016; 33(2):298-302.

6. Eisenstadt I, Nice S, Constantini N, Kerem E, Calderon-Margalit R. Exercise capacity and aerobic physical fitness assessment among adolescents and adults with cystic fibrosis by a questionnaire and exercise tests. Harefuah. 2016; 155(6):352-356.

7. Xiaoqing L. Research on College Students' Physical Exercise Habits Based on Belief in Sports and Fitness-Taking Jimei University as an Example. Sports Science Research. 2019; 023(002):86-92. 